\title{
ANALISA DAN APLIKASI KONSEP "RISIKO" PADA POPULASI WANITA HAMIL
}

Wiwin Wiarsih*

\begin{abstract}
Abstrak
Angka kematian ibu ditentukasn oleh tingkat kesejahteraan individu wanita hamil dalam keluarga. Kondisi ini akan menentukan tingkat kesehtan dan perkembangan anak sebagai satu faktor yang menentukan kesehatan dan menjadi satu indicator dari keejahteraan suatu Negara. Penyebab utama tingginya angka kematian ibu di Negara-negara berkembang adalah belum optimalnya penanganan kasus-kasus berisiko. Penatalaksanaan kasus-kasus berisiko dilakukan terlambat karena kurangnya kesadaran klien untuk mengatasi masalah-masalah kesehatannya, kurangnya informasi, kurangnya jangkauan pelayanan kesehata, dan kurang berkualitasnya sumber daya manusia khususnya pada petugas pelayan kesehatan. Wanita hamil adalah salah satu populasi yang seharusnya diberikan perhatian lebh karena setiap wanita hamil mempunyai kesempatan yang sama untuk mendapatkan penanganan masalah-masalah kesehatan. Faktorfaktor risiko memungkinkanseorang wanita hamil menjadi berisiko tinggi untuk mempunyai masalah-masalah kesehatan, termasuk status sosial ekonomi dan sosio demografi, stress dan gaya hidup, dan praktek kesehatan personal. Untuk menurunkan pengaruh label atau stigma "risiko' dalam masyarakat adalah suatu tantangan untuk profesi kesehatan mengembangkan pendekatan yang efektif dalam pelayanan kesehatan sehingga akan didapatkab suatu hasil yang optimal.
\end{abstract}

Kata kunci: wanita hamil, risiko, faktor risiko

\begin{abstract}
The level of individual well being in a family determines the maternal mortality rate. This condition will determine the level of child health and development as an important determinant of health that is an indicator of well being in a country. The main cause of high levels of of maternal mortality in developing countries as a lack of case management of the "at risk' individual or population; management of "at risk" cases is too late. This is because of lack awareness of "at risk" client in overcoming the problems, lack of information, lack of access to health services, and lack of quality of human resource especially of health care every pregnant woman has the same probability of developing problems. The risk factors enable of pregnant women to become hig risk to have the health problems including socioeconomic status, sociodemographic status, life style and life events, and personal health practices. To decrease the impact of the "at risk" label or stigma in the community, a challenge for the health professional is to develop partnership and multisectoral approach with community so that an optimal outcome will be attained.
\end{abstract}

Key word: pregnant woman, risk, and risk factor. 